\title{
Digitalization of the Russian Federation's economy in the context of global transformation: problems and development prospects
}

\author{
Maryam Orzkhanova ${ }^{1, *}$, Sakhadin Hubolov ${ }^{2}$, and Esma Polyakova ${ }^{3}$ \\ ${ }^{1}$ Ingush State University, Magas, Russia \\ ${ }^{2}$ Kabardino-Balkarian State University named after H.M., Nalchik, Russia \\ ${ }^{3}$ Plekhanov Russian University of Economics, Moscow, Russia
}

\begin{abstract}
The article examines the problems and prospects for the development of the digital economy of the Russian Federation in the context of global transformation. It is obvious that the use of digital technologies in the economic sphere is one of the key indicators of the development of a modern state. The processes of introducing digital technologies are accompanied by technological, economic and legal problems, the solution of which requires government intervention. These circumstances determine the relevance of this study. The purpose of the study is to analyze the problems and assess the prospects for the development of digitalization of the Russian economy, as well as develop recommendations for increasing the efficiency of digitalization of the Russian economy and accelerating the pace of implementation of digital technologies, which will contribute to increasing the competitiveness of the Russian Federation in the world community. The process of digitalization of the economy depends on many factors, the analysis of which will determine the prospects for further development.
\end{abstract}

\section{Introduction}

The Russian Federation has seen significant progress in digital transformation in recent years. The changes are large-scale, they concern all federal authorities, economic and social spheres, and national security. The digitalization of the Russian economy in the context of global transformation is accompanied by a number of problems. Digital transformation is based on certain principles, including data-driven management and analysis.

In this situation, the role of digital transformation leaders is very important, who create an environment for the development of digital technologies in various industries. The digitalization of the economy presupposes, as a matter of priority, the introduction of digital technologies into the activities of individual economic entities.

Economic entities determine the priority areas of digitalization for themselves: the introduction of digital technologies into business processes; database management; management of production, sales and advertising processes.

\footnotetext{
* Corresponding author: fah11061987@ mail.ru
} 
In the Russian Federation, digitalization of processes in all spheres of society's life amounted to $54 \%$ in 2020 . In general, this is a relatively high figure compared to 2018 and 2019.

The regulation of digitalization processes in the Russian Federation is carried out by a number of state bodies, so the Ministry of Digital Development, Communications and Mass Media has developed guidelines for the digital transformation of state-owned companies. Methodical recommendations contain a template structure of the strategy and a set of key indicators for assessing the efficiency [3, p.180].

\section{Study methodology}

Within the framework of this study, scientific methods were used: an analytical review of theoretical information; analysis and processing of statistical information; review of the regulatory framework in the field of digital economy regulation; generalization and presentation of research results in graphical form.

\section{Results of the study}

Digital transformation affects all industries, there are leaders in the implementation of these events, it is obvious that digital technologies are most effectively implemented in the field of IT technologies. Top positions in the ratings are also held by credit institutions, the financial sector, housing and communal services, telecommunications, insurance companies and the oil and gas industry.

For the purpose of an industry analysis of digitalization in the Russian Federation, we will consider the structure of internal expenses of economic entities for the development, distribution and implementation of digital technologies in 2019. Figure 1 shows the structure of internal expenses of economic entities for digitalization activities.

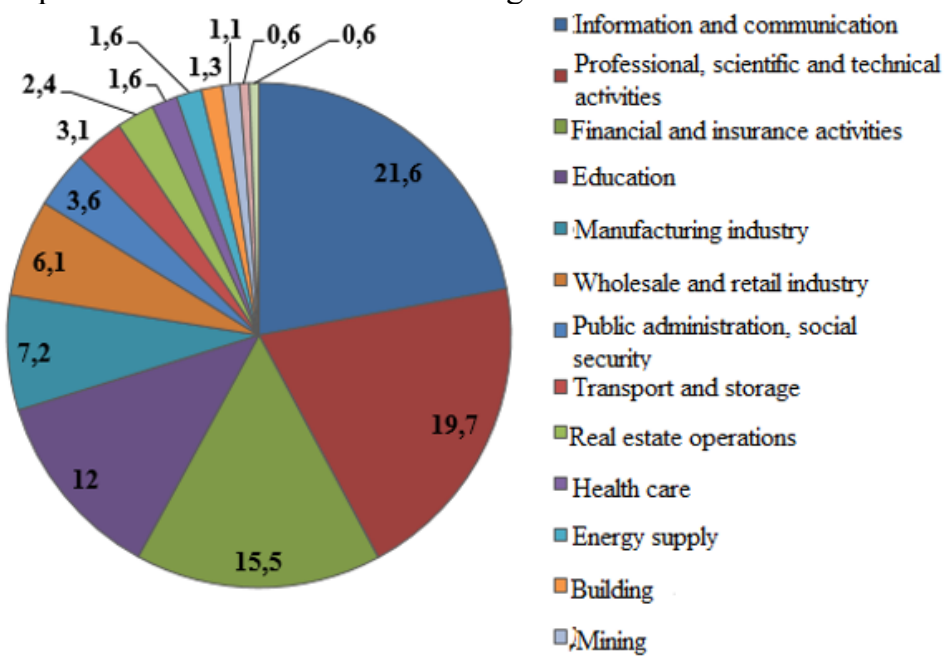

Fig. 1. The structure of internal expenses of economic entities for digitalization activities.

So the greatest expenses were carried out by organizations in the field of information and communication, as well as entities implementing professional, scientific and technical activities. The implementation of pilot projects using artificial intelligence technologies deserves special attention. 
In 2020, the number of pilot projects in the largest organizations increased by $38 \%$ compared to 2019. Companies actively used digital technologies, so up to $85 \%$ used information technology tools.

Digital transformation processes contribute to the emergence of the next industrial revolution in industry, transport and logistics and other industries. However, in addition to positive trends, digital transformation processes have a number of negative trends. [5, p. 176]

The difference in development between organizations and economic entities is growing, the reason for this situation is the presence of differences between the level of digitalization, profitability, and the efficiency of companies.

Digital technologies act as the main factors that allow accelerating and realizing the digital transformation of the economy. Conventionally digital technologies can be divided into 4 groups:

- Internet of things, achievements of artificial intelligence, the development of robotics;

- large-volume databases, 3D technologies, digital modeling;

- quantum and computer technologies;

- blockchain technologies, cyber-physical systems, design.

In this situation, the role of the state is significantly increasing, it should quickly adapt to the ongoing changes and monitor and regulate the situation in the economic and social spheres. The level of digitalization of the economy largely determines the competitiveness of the state in the era of the formation of the information society.

The Russian Federation needs to move to a new level of development of the economic and social sectors. To solve this goal, it is necessary to develop domestic digital technologies, develop science and innovative areas. The state is implementing a number of programs aimed at the development of digital technologies in the territory of the Russian Federation. In 2016, the President of the Russian Federation V.V. Putin signed a decree on the implementation of the "Strategy for the scientific and technological development of the Russian Federation." In 2019, the national program "Digital Economy of the Russian Federation" was approved, which defines the goals, objectives, tools and prospects for the development of the digital economy in Russia. [1]

Within the framework of this strategy, measures are outlined aimed at creating regulatory, technological, financial and organizational conditions that ensure the efficient development of the digital format of the economy in Russia. In April next year, the head of state approved a regulation, within the framework of which a working group was formed to implement the tasks outlined in the strategy. The main tasks of this group are the development and implementation of a concept for the formation of a digital economic space.

The introduction of digital technologies is primarily focused on accelerating the pace of development. The digitalization processes in the Russian Federation have intensified significantly over the past 5 years, but pursuant to a number of indicators, the level of development of digital technologies is lower than in developed European countries [9, p. 163].

Figure 2 presents the World Digital Competitiveness Ranking. The leading position is occupied by the United States. Among European countries, the leading positions are occupied by Sweden, Denmark, Switzerland. In these countries, the development of digital technologies is at a very high level. China has significantly enhanced its position. 


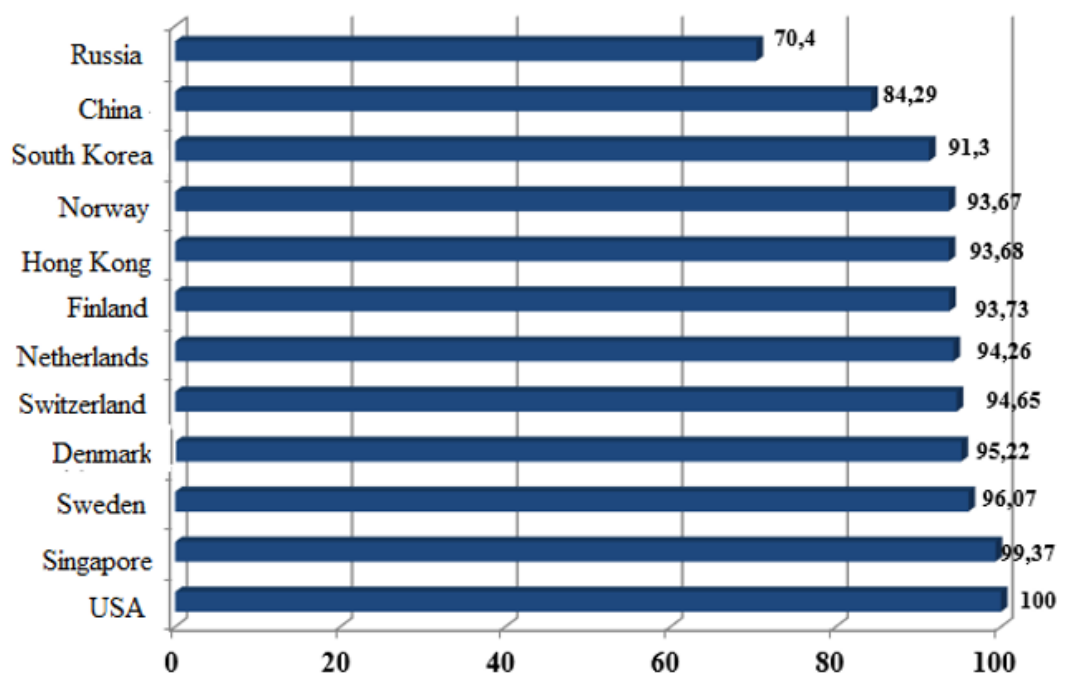

Fig. 2. Positions of the leading countries, Russia and China in the Global Digital Competitiveness Index for 2019.

The positions of the Russian Federation are not so high, but it should be noted that the situation is improving every year. Knowledge, technology and readiness for the future were used as criteria for assessing the competitiveness of the digital economy.

\section{Discussion of results}

The reasons for the slow development of the digital economy in the Russian Federation in comparison with the United States and European countries are the slow development and implementation of digital technologies from a technological perspective, a low growth rate of labor productivity and a small share of financial financing of the digital economy in the country's GDP. Figure 3 shows the costs of developing the digital economy as a percentage of countries' GDP. Compared to Finland, Denmark and Belgium in Russia, the cost of developing digital technologies in the economic sector is lower. Accordingly, the amount of funding has a direct impact on the development of digital technologies in the economy.

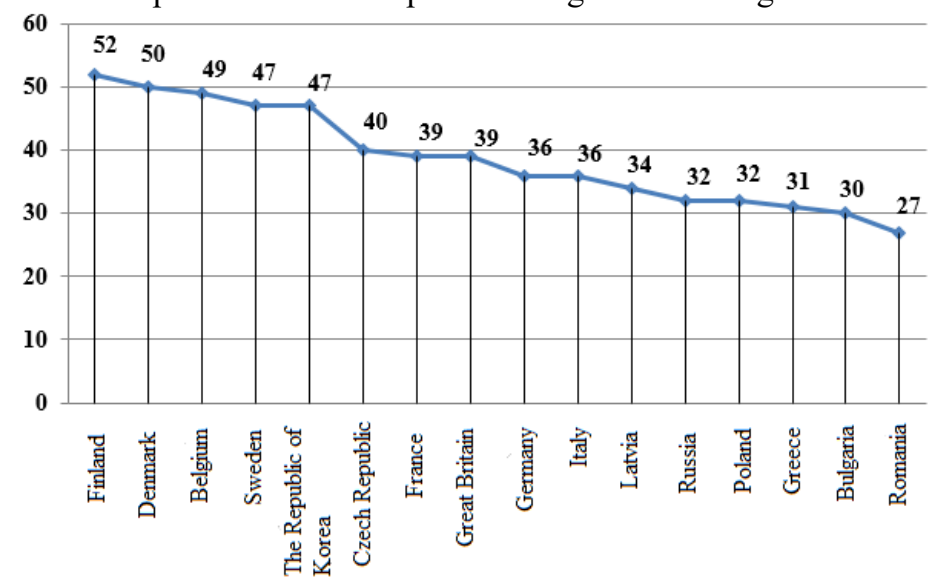

Fig. 3. Expenditures for the development of the digital economy as a percentage of the RF GDP. 
In the Russian Federation, the costs of developing digital technologies are increasing every year, since digitalization processes are inevitable and necessary to increase competitiveness in the global market. Figure 4 shows the costs for the development of the digital economy as a percentage of the GDP of the Russian Federation, there is a relatively low, but still an increase in the share of costs, which will largely contribute to the development of the digital economy.

The introduction of digital technologies is closely related to the level of economic and information security in the state. It is very important for Russia at this stage to increase the level of economic and information security in order to successfully complete the initial stage of digitalization of the economy and further development. The solution of these tasks will increase the position in international rankings [8, p.67].

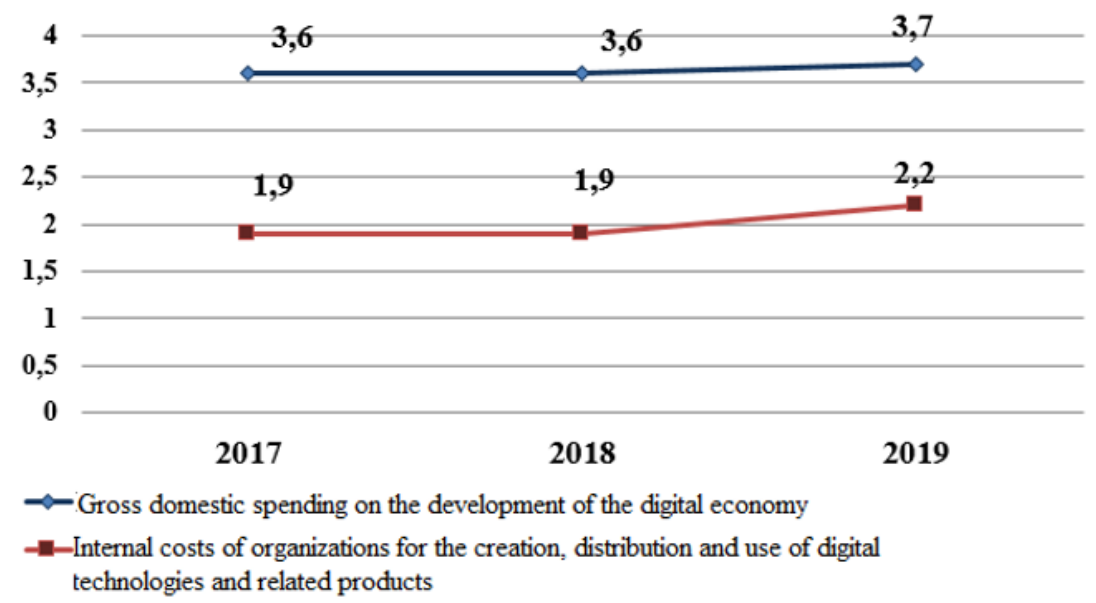

Fig. 4. Costs for the development of the digital economy as a percentage of GDP in the Russian Federation.

In Russia, experts in the development and implementation of digital technologies also note the strengths for the development of the digital economy:

- a high level of accessibility of information technologies, great attention is paid to the development of an accessible information environment;

- development of the population's abilities to use information and communication technologies, projects have been developed and implemented to increase the level of information and financial literacy;

- high level of education and literacy among the adult population;

- development of information and communication infrastructure, creation of information centers, institutions.

In 2020-2021, the main trends in digital transformation of companies in Russia have emerged:

- specialized digital platforms for individual industries are being developed and implemented, which significantly expand opportunities for business development, but threats also arise;

- transformation of customer experience, large-scale automation and development of a management model built on the basis of data and a significant acceleration of the practical implementation of technologies for the digitalization of the economy;

- the use of robot technologies, a developed analytics system, the development of processes for working with big data; 
- the infrastructure of Russian organizations is adapted to the introduction of new digital technologies; development of developments in the field of business applications for digital solutions;

- the emergence of problems in the field of personnel policy: a low percentage of employees with relevant competencies in the field of digital technologies;

- automation of most work processes and reducing the need to implement work operations in a traditional format;

- implementation of government programs aimed at financing projects in the field of business digitalization for economic entities.

\section{Conclusions}

High-quality and efficient growth of the digital economy is possible only with the availability of information technologies that will allow the most accurate monitoring and analysis of market conditions and sectors of the economy.

Digitalization, in addition to affecting all sectors of the economy, contributes to the emergence of new markets and industries that have a specific network nature. In Russia, the state's attention is focused on markets that create opportunities for the development of industries of a new technological order. The development of technological industries will contribute to providing an efficient platform for the formation of a modern and comprehensive system of the digital economy [10, p.57].

Digital platforms for managing the economy will form the foundation for the introduction of new information and innovative technologies. These measures will ensure the advanced development of Russia in comparison with Western and European countries.

An analysis of the digitalization of the Russian economy in the context of global transformation has revealed a number of problems. Solving the identified problems, possibly through the implementation of the following measures:

1. The national project "Digital Economy of the Russian Federation" needs to be finalized and further appropriate changes should be made pursuant to the trends in the development of digital tools in the world.

2. Development and implementation of a system of incentives for organizations related to digitalization, the development of digital technologies. There are companies in Russia that hold leading positions in the digital economy: Kaspersky Lab, Yandex.

3. Support for the development of small and medium-sized businesses engaged in the development of digital technologies and providing services in a digital and technological format.

4. Improvement of personnel policy in the field of information technology. Development of an educational system for training new teaching staff. The purpose of the development of the educational system is to increase the level of training of specialists, which will solve the problem of the shortage of personnel in the field of information technology.

5. Formation of a sustainable cybersecurity system. Thus, in the field of legal regulation, it is necessary to make a number of changes and enhancements, and more attention should be paid to the issues of technological refinement, which will minimize the number of cyberattacks. It is necessary to maximally protect the interaction between objects and subjects of the global digital economy.

6. Active introduction of scientific and technical developments in the field of economics. The most important condition for the development of the digital economy is the development and implementation of scientific and technical developments.

7. Creation of new legal institutions in the field of digital economy regulation. Sectors of the digital economy should be regulated by special regulations. The formation of a regulatory and legal foundation for regulating relations in the digital economy will contribute to the 
development of a new format economy in the Russian Federation and increase competitiveness in the world market. The rules for disclosing any kind of information, copyright protection in the network, financing of innovative developments - all this should be regulated by certain standards.

\section{References}

1. Natsional'naya programma «Tsifrovaya ekonomika Rossiyskoy Federatsii»: utv. prezidiumom Soveta pri Prezidente RF po strategicheskomu razvitiyu i natsional'nym proyektam, protokol ot 04.06.2019 № 7. http://www.consultant.ru

2. O natsional'nykh tselyakh i strategicheskikh zadachakh razvitiya Rossiyskoy Federatsii na period do 2024 goda: Ukaz Prezidenta Rossiyskoy Federatsii ot 07.05.2018 g. № 204 . http://www.kremlin.ru

3. A. Ye. Zubarev, Vestnik TOGU 4 (47), 177 (2017)

4. N.R. Kamynina, Ekonomika i upravleniye narodnym khozyaystvom 1 (170), 29 (2019)

5. N. K. Norets, A.A. Stankevich, Tsifrovaya ekonomika: sostoyaniye i perspektivy razvitiya. Innovatsionnyye klastery v tsifrovoy ekonomike: teoriya i praktika, 173 (2017)

6. S.S. Nosova, V.V. Ryabtsun, A.N. Norkina, Ekonomika i predprinimatel'stvo 3(92), 26 (2018)

7. R.A. Timofeyev, D.R. Minibayeva, Ye.A. Yekhlakova, Vestnik ekonomiki, prava i sotsiologii 1, 42 (2018)

8. F.A. Khochuyeva, T.L. Shugunov, A.Z. Zhukov, CH.KH. Ingushev, Sovremennyye naukoyemkiye tekhnologii 11(1), 65 (2018)

9. N.L. Udaltsova, Quality-access to success 21 (175), 162 (2020)

10. G. P. Litvintseva, I. N. Karelin, Terra Economicus 18(3), 53 (2020) 